\title{
IMPACTS OF DRINKING WATER PROJECT ON LIVELI- HOOD OF RURAL WOMEN
}

Bhim Prasad NEUPANE

\section{ABSTRACT}

Based on the study of PUDWP (Pelakot Udiyachour Drinking Water Project) area of Syangja district the study construed that with access to water, there has been an increase in instances of animal rearing and kitchen gardening. It is saving time of the women due to the installation of tap water supply thus helping women to carry out other activities. For the women of the poor and poorest households, the time saved has helped them to include in livestock raising and agricultural activities and wage labour, thus, contributing to their household economy and women empowerment.

KEY WORDS- Participation, Empowerment, Internalization, Impacts, Gender-sensitive

\section{BACKGROUND OF THE STUDY}

With the rise of different development paradigms like Women in Development (WID) and Gender and Development, (GAD) more gender sensitive and women specific policies and strategies have been evolving in drinking water sector. Various policies and planning are made focusing on fulfilling water need of people but their implementation has been remaining very weak ones. Sociological analysis can guide the society an appropriate change as well as planning way of water sector of Nepal. A study of gender relations, which encompasses the interactions between women and men in various domains and power relations between the two senses, is a prerequisite for the understanding the situations of women. Any gender sensitive development information, for instance drinking water supply system, is expected to play a vital role in facilitating positive changes in gender relations. Helping to organize women users to have equal access and ownership along their male counterparts in management of drinking water supply system is an example of gender relations. However, as Uprety (1999) claims, water sector activities need to be gender-sensitive at all levels, from policy-down to community activities, and gender concern need to be 
Impacts drinking water...... Neupane

integrated in policies, plans, programs and projects. More gender specific data are required in the water sector. Women play the central part in the provision, management and safeguarding of water. An important aspect of gender based analysis is that it moves away from women's issue to considering structures that effect and are affected by both men and women (Bullock, 1994).

This research investigates the role of drinking water supply system in bringing about changes in gender relation and changes in the society in semi-rural setting of Nepal. The focus of the study is to analyze the impacts on the lives of women-water collectors and their gender roles by the water supply system before and after the drinking water project.

\section{PROBLEM AND OBJECTIVES}

The social and economic implication of drinking water project on women could be viewed in two ways: (i) women as recipient of the benefits of water supply program; and (ii) women's participation in the project (particularly in the construction and post construction phase). The gender identities are the conceptions we have of ourselves as beings male and female and the knowledge that one is a male or a female and the internalization of this fact into one's self-concept (Lawman, 2004).

Time saved from availability of drinking water is an important aspect, but it may not necessarily suggest that women's overall work load has been decreased or that the saved time is being utilized for meeting her other needs necessary for improving her status within family and society at large. This issue must be analyzed from micro level studies within depth sociological perspectives to reveal the changes that have come about in the daily time management of the women. Moreover, it is expected that it makes some contributions to make the understanding of the nature and context of the problems associated with the drinking water and related social problems vivid. In other words, the importance of the changes brought about during and after the intervention of drinking water supply in a particular society to address the strategic needs of women should be one principal area to look for its impacts on gender relationship. The concept of gender in development is abstract and opens up for the realization of women's productive potentials in 
development (Ostergaard, 1997). This study focused on the following research questions:

1. What necessitated the beginning of the drinking water project in the village? How was the project initiated and eventually constructed?

2. How did the women contributed in the construction of the project?

3. How was the women's working pattern in the domestic affairs before the implementation of the project?

4. Is there any change in the working pattern of the women after the construction of the project? If yes, in what ways?

5. Is the project leading to the women empowerment? If yes, how?

Thus, the general objective of this study was to explore and understand the major impacts of PUDWP among the women of the study area. But it had three-fold specific objectives as below:

1. To identify the women's participation in PUDWP's activities.

2. To analyze the role of PUDWP in changing women's daily working pattern.

3. To study the contribution of PUDWP in women empowerment.

Fig 1: Conceptual Framework of the Study

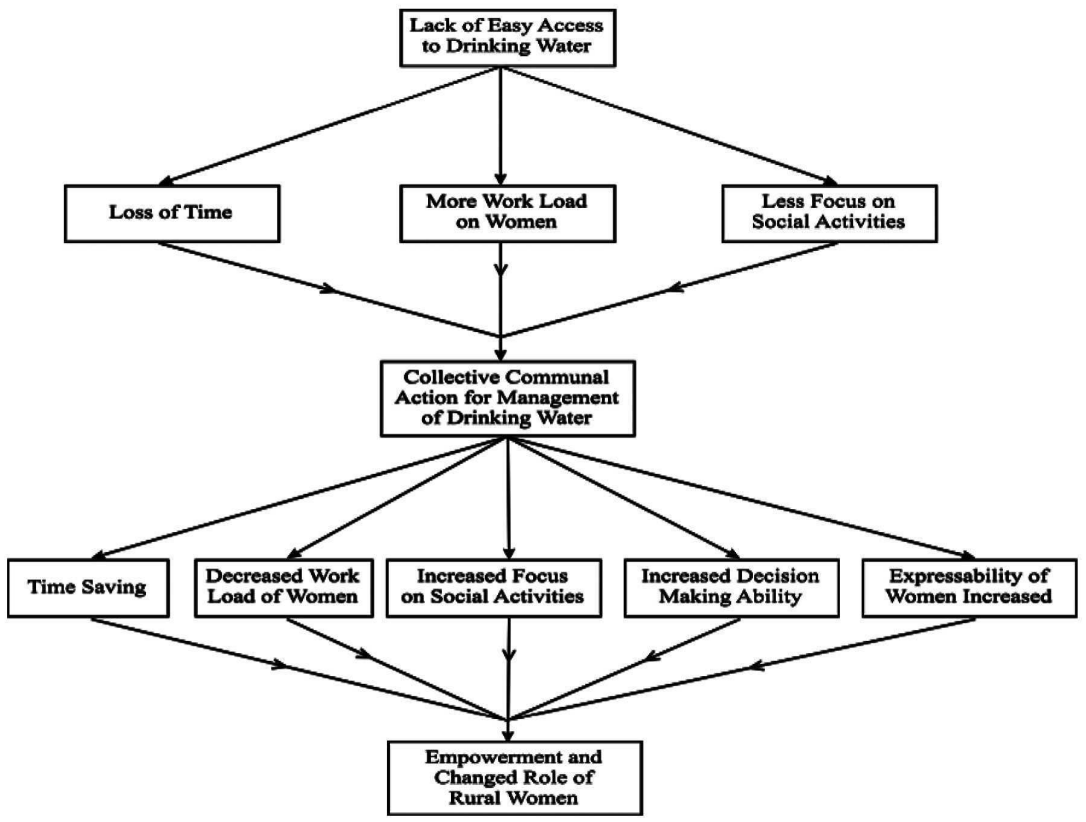


Impacts drinking water...... Neupane

Conceptual framework makes it clear that lack of easier access to drinking water created heavy work load on women as they had to allocate more time for collecting water and they had little attention on social activities. But their collective awareness and participation of women along with other members of society ensured the construction of drinking water project. Their continuous engagement in construction and management of drinking water project increased their decision making power, promoted the attitude of active participation and saved their time. Now they are getting empowered and contributing more and more welfare of self, family and the whole society.

\section{RESEARCH METHODS}

Pelakot VDC, in Syangja is the study site. PUDWP (Pelakot Udiyachour Drinking Water Project) area is $30 \mathrm{~km}$ far from district headquarter of Syangja district. The total of one hundred and fifty eight water user households constituted the study universe of Pelakot VDC of Syangja district. Households were taken as sample unit for the study. Of the total households, 54 households were sampled purposively. The households were stratified on the basis of earning to allow representation from all categories crick-poor all castes/ethnic groups, religions of water user households. Household survey, interview schedule, direct observation and key informants interview were used as tools and techniques of primary data collection.

\section{WOMEN PARTICIPATION IN PUDWP'S ACTIVITIES}

As stakeholders of the PUDWP, women of Pelakot, Udiyachaur village have participated in the activities of this drinking water project in various ways during its construction. Strong participation of women resulted in the successful installation of hand pumps and latrines and a noticeable decline in diarrhea and other disease (World Bank, 1993). The main ways in which the women of Udiyachaur participated in the PUDWP's activities are as follows:

\section{COMPARISON OF CONCERN OF WOMEN AND MEN ABOUT DRINKING WATER FACILITIES}

Water is always an issue of concern for all people since it is one of the 
basic needs. Gyawali (2001) argues that water is one aspect of whole that is the Nepali society and her resources. The concern shown by women was very much encouraging right from the need assessment of this project. Their deep concern about this project was one of the major factors behind the success of this project. The figure clarifies:

Figure 2 Comparison of Women/Men Concern about Drinking Water Facilities

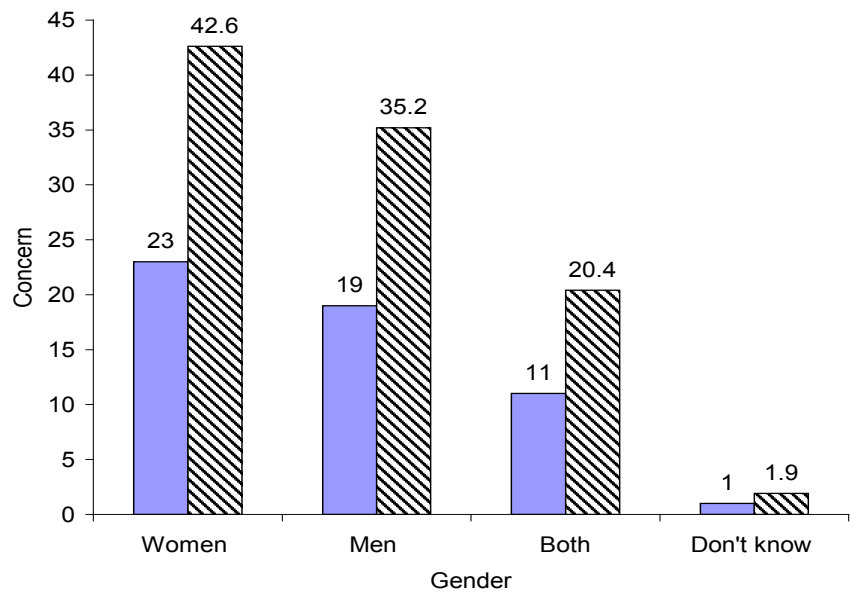

Source: Field Survey, 2007

As shown in the figure, 42.6 percent of the respondents felt women were and are more concerned with the construction of the drinking water project while 35.2 percent felt men as more concerned and 20.4 percent believed that both men and women were concerned about drinking water project. These data clearly show that women have more concern about drinking water facilities than that of men. This is due to the fact that like in other Nepalese societies, in Udiyachaur also women are allocated with the responsibility of collecting drinking water and previously the major water sources for them were located at far off places from their locality.

\section{INVOLVEMENT OF WOMEN DURING THE CONSTRUCTION OF THE PROJECT}

As encouraged by their concern about easier access to water, women were very actively engaged in the construction of the project; one way their self-concern encouraged them to participate in drinking water project activities. The given table shows some data regarding this matter. 
Impacts drinking water...... Neupane

Table 1. Possession of the Feeling of Self-Encouragement by Women to Participate in the PUDWP's Activities

\begin{tabular}{|l|l|l|}
\hline Category & Frequency & Percent \\
\hline Yes & 42 & 77.8 \\
\hline No & 5 & 9.3 \\
\hline Don't know & 7 & 13.0 \\
\hline Total & 54 & 100.0 \\
\hline
\end{tabular}

Source: Field Survey, 2007

A large portion i.e. 77.8 percent of the respondent women felt that they were encouraged themselves to participate actively in PUDWP activities. This also reflects the general scenario of the most of the rural women. This is because they have been the one who have a direct relationship with water-fetching activities in day to day life. Due to a long distance of the water source, these women have been facing a great work burden. Women were self encouraged participating in PUDWP activities; it was natural for them to perceive each others' contribution of higher one.

Figure 3. Level of Participation of Women during the Construction of PUDWP

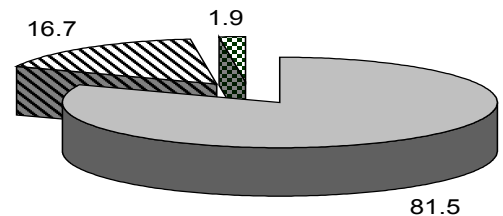

Source: Field Survey, 2007

As shown in the figure, 81.5 percent of the respondents thought that there was a very high level of participation of women during the construction of the PUDWP. While16.7 percent viewed it a satisfactory one from their side. This also clearly shows the level of desperation of having an easier access to drinking water facility for these women. Definitely they seemed to lessen the workload on them regarding the management of water for household uses. 
3. PARTICIPATION OF WOMEN AFTER THE COMPLETION OF PROJECT CONSTRUCTION

The type of activism that women showed during the construction of PUDWP remained almost the same even after the completion of the project. The researcher also noted such activism in the part of women in PUDWP viewed. The way women visualized each other's construction in PUDWP after its construction is shown in table below:

Table 2. Level of Participation of Women after the Construction of the PUDWP

\begin{tabular}{|l|c|c|}
\hline Category & Frequency & Percent \\
\hline Very Active & 49 & 90.7 \\
\hline Satisfactory & 2 & 3.7 \\
\hline Poor & 2 & 3.7 \\
\hline No response & 1 & 1.9 \\
\hline Total & 54 & 100.0 \\
\hline
\end{tabular}

Source: Field Survey, 2007

The table shows that a large proportion of the women respondents i.e. 90.7 percent viewed each other's involvement in PUDWP after its construction as very active while 3.7 percent of them viewed it satisfactory. Actually this contribution of women after the project construction was centered more on its maintenance and discussion made about the durability of the project. Their perception was further vindicated by one of the key informants who explained that women have been more active than in the past to make the project durable.

\section{INVOLVEMENT OF WOMEN IN OPERATION AND MAINTE- NANCE}

The operation and maintenance is one of the important activities of any drinking water program. The longevity of any project rests on the level of commitment shown by its stakeholders in its promotion and maintenance. Women of Udiyachaur have played extremely important role for the processes of operation and maintenance of this project. The researcher also recorded some cases supporting this fact during field 
observation. The following figure shows the real scenario of women's participation in the operation and maintenance of this drinking water project.

Figure 5 Involvements of Women in Operation and Maintenance

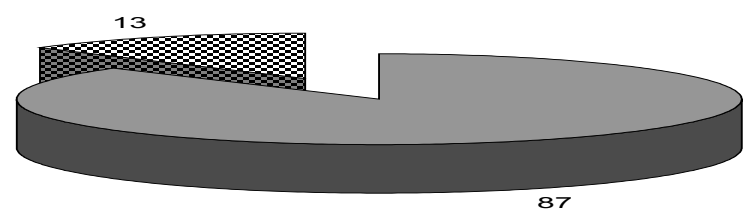

Source: Field Survey, 2007

E No

After the construction of the PUDWP, 87 percent of the women respondents said that they were continuously involved in the operation and maintenance of the project after its successful completion, while 13 percent of them expressed that they were not doing so currently. Higher involvement of women in the operation and maintenance may be due to the presence of fewer numbers of men in the village since a large number of them are now in the foreign employment. This scenario is now becoming a characteristic feature of most of the Nepalese villages.

\section{ROLE OF PUDWP IN CHANGING WOMEN'S WORKING PATTERN}

The working pattern of the women in the households of Udiyachaur is not much different from that of most of the Nepalese rural women. Most of their time is spent on domestic affairs. In the past, fetching water from distant source was familiar and one of most difficult household tasks for rural women. They had to spend a long time for fetching water in Udiyachaur too. But once the PUDWP was built, some significant changes occurred in the working pattern of women due to time saving.

\section{TIME SPENT FOR COLLECTING WATER BEFORE THE PRO- JECT CONSTRUCTION}

Since women had to visit spring or well for collecting water before the project construction, naturally it required these women to allocate a long time for fetching water. This was because these water sources were far from their houses. The given table shows more information on it. 


\begin{tabular}{|l|c|c|}
\hline Category & Frequency & Percent \\
\hline $0-10$ minutes & 6 & 11.1 \\
\hline 10-20 minutes & 2 & 3.7 \\
\hline $20-30$ minutes & 24 & 44.4 \\
\hline 30 minutes above & 22 & 40.8 \\
\hline Total & 54 & 100.0 \\
\hline
\end{tabular}

Source: Field Survey, 2007

As the table shows that 44.4 percent of the women respondents had to spent more than 20-30 minutes for fetching water while 40.8 percent had to spent more than 30 minutes, 11.1 percent had to use 10 minutes or less and 3.7 percent had to spent10-20 minutes for collecting water. This shows the real problem that these women faced before the project construction in which they had an excessive work related to fetching. In fact, this scenario still prevails in many rural areas of our country as a bitter truth.

\section{WORKING PATTERN OF WOMEN RELATED TO DRINKING WATER SUPPLY AFTER PUDWP'S CONSTRUCTION}

Obviously, PUDWP has brought significant changes in the working pattern of the women of Udiyachaur in terms of managing water for household purpose and others. In a way, now they are tasting the fruit of their honest labor and contribution they did in the process of the project construction. The major changes brought by the project in women's working pattern in the village have been described as follows:

\subsection{EASY ACCESS TO WATER SOURCES}

After PUDWP's construction, the women of Udiyachaur are quite happy due to easy supply of water on or near their courtyard. This has eased the basic processes of bathing to general irrigation of the kitchen garden. The availability of water near the courtyard has definitely saved their time allocated for managing water. Women's work load is greatly lessened after the PUDWP's construction. As a result, women are gradually shifting towards some productive and creative activities. This has added a new dimension towards the empowerment of rural women. 


\subsection{USE OF WATER FOR KITCHEN GARDENING}

Women are using water for other purposes such as irrigating vegetables in the farm and kitchen garden. Women have started seasonal and off-seasonal vegetable farming near their households after the project construction. They are able to generate certain income at the household level. Women have also been able to make economic profit from vegetable farming. This has lessened their economic dependency on their husbands and is empowered economically.

\subsection{CONVENIENCE}

The PUDWP's construction has not only saved time for collecting water for these women of Udiyachaur but also has made their difficult task of managing water for household chores a convenient one. Better access to water improves women's health, income and liberates them from daily drudgery of fetching water (Koppen, 2001).

\subsection{CHANGE IN HOUSEHOLD DIVISION OF LABOUR}

Nepalese society is traditionally male dominated. Men are ranked higher to women and the activities that men perform are considered to be more superior to women. This scenario also prevails in the household sector also in the society of Pelakot. After the PUDWP's construction, some significant changes have been recorded regarding the household division of labour among men and women.

\section{ROLE OF PUDWP IN WOMEN EMPOWERMENT}

PUDWP has proved to be very helpful to empower the women at Udiyachaur in Pelakot VDC, Syangja as quoted by one of the key informants. PUDWP has played its role in women empowerment in this village.

\section{USE OF SAVED TIME BY WOMEN}

One of the most the significant contributions of this drinking water supply project on women's lives has been the duration of time saved that they had to allocate for fetching water. As a result now they have been able to involve themselves in various creative activities. Such 
kinds of involvement of these women have been adding a new dimension to women empowerment. The following table shows the pattern in which these women have been using the time saved for fetching water after the construction of the PUDWP.

\section{INVOLVEMENT IN INCOME-GENERATION}

Women have been able to generate same income by using the saved time from fetching water. Most of these women have been using that saved time in agriculture and have started kitchen gardening after the easy availability of water. From the kitchen garden, these women are now producing some vegetables and cash crops around home by using the saved time after the construction of the PUDWP. This has proved to be a quite beneficial for these women besides fulfilling the family need of vegetables. The income that they have been making from such activity has been a supplement to support the household economy.

\section{LEADERSHIP DEVELOPMENT}

Another very important and significant contribution of PUDWP has been the leadership development among women as explained by one of the key-informants concerned with PUDWP managing committee. Their regular participation in meeting in the course of construction and management of PUDWP has made them more conscious and aware about various issues related to leadership development.

\section{INVOLVEMENT IN DECISION-MAKING}

Along with leadership development, involvement in decision making in the family and the society has been another dimension of women empowerment in Udiyachaur after the PUDWP's construction. In most of the phases of PUDWP's construction women were involved actively in new decision-making regarding the project.

\section{DEVELOPMENT OF PARTICIPATORY ATTITUDE}

With the construction of the PUDWP, the participatory attitude of women is also enhancing. 


\section{CONCLUSION}

With access to water, there has been an increase in instances of animal rearing, kitchen gardening, in which the majority of the households are engaged. The PUDWP has been successful in saving time of the women due to the installation of tap water supply thus helping women to carry out other activities. For the women of the poor and poorest households, the time saved has helped them to include in livestock raising and agricultural activities and wage labour contributing to their household economy. But for the women of the rich and medium households it has added more work burden for vegetable farming and milk selling as an income generation activity employed has failed to bestow them with the anticipated economic welfare. Hence it has only come about as an added income in the households of the rich and moderate households but it has had an impact on the autonomy of the women.

The gender relationship in PUDWP has been witnessing changes although the differences are not astounding. The first change comes about with milked animal rearing where women become major milk sellers of the village. The second major change is instigated by piped water supply installation. During the process, women were compelled to attend meetings. Qualitatively, their participation rate becomes higher. Nevertheless the step has brought out the realization among the men that women should be a part of the community development activities. PUDWP provides more time for women to partake in discussion programmes with males, income generating activities like portaging, liquor brewing and livestock farming. The household division of labor between husband and wife is also becoming equal. As member women who earns, have increasingly begun to intervene at the decision and have begun to acquire much significance. The women presently get opportunities and encouragement for men of their household and villagers to participate in community activities like cooperative, school management, forest management, Kulo committee, etc. women may not be as active as men during the meetings but unlike ealier time (before PUDWP), women now seek clarification on matters they are not able to understand. 


\section{REFERENCES}

Bullock, Susan (1994). Women and Work Women and World Development Series. London: Zed Publications.

Gayawali, Dipak (2001). Water in Nepal. Kathmandu, Himal Books and Panos South Asia, with Nepal Water Conservation Foundation

Koppen, V. B. (2001). "Empowering Women to Achieve Food Security and Water Rights", A Paper Presented to IFPRI, Washington D.C.

Lawman, Niomi (2004). Illustrated Dictionary of Sociology. New Delhi, Lotus Press: New Delhi

Ostergaard, Lise (1997). Gender and Development: A Practical Guide, First Edition, London: Routledge.

Uprety Laya, P. (1999). "A Review Paper on Social Component in Water Resources Strategy Formulation." Kathmandu, A Paper Submitted to Consolidated Management Services, Nepal (P): Ltd. Nepal.

World Bank. (1993). Water Resource Management Policy Paper. World Bank 